Конюкова Ірина Янівна кандидат педагогічних наук, дочент Київський наиіональний університет культури і мистецтв Київ, Україна konyukova@ukr.net

\title{
ПРОФЕСІЙНА ЕТИКА БІБЛІОТЕКАРЯ: ЗАБЕЗПЕЧЕННЯ ВІЛЬНОГО ДОСТУПУ ДО ІНФОРМАЦІї ЧИ СОЦІАЛЬНА ВІДПОВІДАЛЬНІСТЬ?
}

Мета роботи - обгрунтувати значимість ролі бібліотекаря в захисті інтелектуальної свободи як важливого складника демократичного суспільства, та окреслити проблемне коло питання свободи доступу до інформації і етичних ситуацій у діяльності бібліотекаря, як інформаційного посередника, який надає до неї доступ. Методологічна основа дослідження - принципи історизму, об'єктивності та системності. Застосовувалися також загальноісторичні та історико-соціологічні методи, зокрема, історико-порівняльний, історико-ретроспективний, історикотипологічний, статистичний. Серед спеціальних методів дослідження особливе значення мали методи порівняльного бібліотекознавства. Наукову новизну становить аналіз професійної етики бібліотекаря як сукупність специфічних вимог і норм моральності при виконанні ним професійних обов'язків по 
обслуговуванню споживачів інформації. Висновки. Свобода доступу до інформації, сформульована як вища морально-етична цінність у професійній діяльності бібліотекаря сьогодні потребує уточнення і дискусії в науковому співтоваристві та в середовищі професійної бібліотечної спільноти. Беручи до уваги динамічні соціокультурні зміни в інформаційному просторі імперативом $\epsilon$ наукові дослідження проблем інформаційної етики й освітня підтримка (у будь-яких формах навчальної діяльності) діяльності бібліотекарів-практиків.

Ключові слова: професійна етика бібліотекаря, культура спілкування, морально-етичні норми, правила етикету.

Конюкова Ирина Яковна, кандидат педагогических наук, Киевский Национальный университет культуры и искусств, Киев, Украина

Профессиональная этика библиотекаря: обеспечение свободного доступа к информации или социальная ответственность?

Цель работы - обосновать значимость роли библиотекаря в защите интеллектуальной свободы как важной составляющей демократического общества. Методологическая основа исследования - принципы историзма, объективности и системности. Применялись также общеисторические и историкосоциологические методы, в частности, историко-сравнительный, историко-ретроспективный, историко-типологический, статистический. Среди специальных методов исследования особое 
значение имели методы сравнительного библиотековедения. Научную новизну составляет анализ профессиональной этики библиотекаря как совокупность специфических требований и норм нравственности при выполнении им профессиональных обязанностей по обслуживанию потребителей информации. Выводы. Свобода доступа к информации, сформулирована как высшая морально-этическая ценность в профессиональной деятельности библиотекаря сегодня нуждается в уточнении и дискуссии в научном сообществе и в среде профессиональной библиотечного сообщества. Принимая во внимание динамические социокультурные изменения в информационном пространстве императивом является научные исследования проблем информационной этики и образовательная поддержка (в любых видах и формах учебной деятельности) деятельности библиотекарей-практиков.

Ключевые слова: профессиональная этика библиотекаря, культура общения, морально-этические нормы, правила этикета.

Koniukova Iryna, PhD of Pedagogic Sciences, Associate Professor, Kyiv National University of Culture and Arts, Kyiv, Ukraine

Professional ethics of librarianship: providing free access to information or social responsibility?

The purpose of the article is to substantiate the importance of the role of the librarian in the protection of intellectual freedom as an important component of a democratic society. The research methodology was based on the principles of historicism, objectivity and 
consistency. General historical and historical-sociological methods were also used, in particular, the historical-comparative, historicalretrospective, historical-typological, and statistical. Among the fieldspecific methods of research, methods of comparative library science were of particular importance. The scientific novelty of the work lies in the analysis of the professional ethics of librarianship as a set of specific requirements and norms of morality in the process of performing professional duties to provide service to consumers of information. Conclusions. Freedom of access to information, defined as the highest moral and ethical value in the professional activity of a librarian, needs clarification and discussion today in the scientific and professional library communities. Taking into account the dynamic socio-cultural changes in the information space, the imperative is scientific research into the problems of information ethics and educational support of the activity of librarians-practitioners (in any kinds and forms of educational activity).

Key words: professional ethics of librarianship, communication standards, moral and ethical norms, etiquette rules.

Вступ. Оскільки предмет нашого дослідження стосується таких понять як «інформаційна етика», «свобода доступу до інформації», «професійна етика бібліотекаря», звернемось до праць науковців, які дадуть змогу окреслити сучасні погляди на ці поняття в науковому дискурсі.

Відкритість доступу до інформації в сучасних умовах $\epsilon$ предметом уваги науковців. У статті Н. Махотіної [6] розглянуто 
міжнародну практику в галузі обмеження доступу до інформації, i зазначається, що держава має право обмежувати доступ громадян до інформації у межах чинного законодавства - 3 метою захисту конституційного ладу, моральності, прав і законних інтересів інших осіб. Н. Махотіна також робить висновок про те, що межа між рішенням бібліотекаря про неможливість 3 етичних міркувань рекомендувати те чи інше видання й утиском прав особистості $€$ досить умовною.

Стосовно основного постулату про забезпечення вільного потоку інформації та ідей, в роботі О. Козлової [5] зазначено, що в переважній більшості «Кодексів професійної етики бібліотекаря» встановлено, що бібліотекар розглядає вільний доступ до інформації як невід'ємне право особистості, протидіє обмеженню доступу до бібліотечних матеріалів і не допускає необгрунтованої відмови (цензури) на запити документів. Як виняток, дослідниця наводить кодекс Швейцарії «Професійна етика бібліотекарів», де розділ «Доступ до документів» містить умову, яка рекомендує бібліотекарям деяку обачливість і відповідальність за результати своєї праці: «...може мати місце випадок обмеження вільного доступу 3 вищих етичних міркувань. Це може стосуватись користувачів, яких бібліотекарі повинні захищати (наприклад, дітей)» [5].

Стосовно загальнометодологічного розуміння інформаційної етики розглянемо праці з філософії. У роботі Г. Миролюбенко [7] поставлено за мету дослідження інформаційної етики як нової галузі прикладного етичного знання, виявлення їі морально- 
етичного потенціалу в розв'язанні колізій, що виникають в інформаційному просторі. Новизна дослідження, як представляє автор, полягає не тільки в тому, що вперше на теренах України проблема становлення та розвитку інформаційної етики представлена як предмет дисертаційного дослідження, а й одержано наукові результати, які свідчать, що:

- теорія інформаційної етики має онтоцентричний характер, адже проголошує онтологічну рівність усіх форм дійсності. Інформаційна етика оцінює поведінку індивіда через поняття «розширення інфосфери», а будь-яка дія, направлена на ii спотворення розглядається як негативна;

- інформаційна етика як ціннісно-нормативний регулятор масмедійного та віртуального середовища виступає інструментом самоорганізації суб’єктів комунікації через консенсусно-договірні механізми.

Науковець стверджує, що основні проблеми, до яких звертається інформаційна етика, а саме анонімність, порушення приватності та авторського права, хакерство, інформаційне піратство виникають у наслідок розв'язання нових типів інтерсуб’єктивних стосунків, які стали можливими 3 появою Інтернету.

У дослідженні І. І. Чхеайло, та А. А. Чхеайло [13] стосовно інформаційної етики як моральної регуляції сучасного суспільства зроблено висновок, що інформаційна етика займається аналізом соціальних і особистісних впливів інформаційних технологій. Їі основне завдання полягає в конкретизації моральних норм з метою 
регулювання людської поведінки в сфері створення і використання комп’ютерних технологій.

У своїй статті М. О. Кириченко, розмірковуючи над значенням інформаційної антропології та інформаційної етики, зазначає, що «...їх дослідження як складників ідеології інформаційного суспільства розглядається як глобальний цивілізаційноінформаційний процес, націлений на те, щоб підготувати суб'єкта до оброблення величезних обсягів інформації в суспільстві, яке називають постінформаційним чи технотронним». У статті зроблено висновок, що «...ідеологія інформаційного суспільства своєрідний комплекс інформаційних повідомлень, вірувань, поглядів, що становлять інформаційне поле, як головних конструктів інформаційного суспільства - інформаційної антропології та інформаційної етики» [4, с. 53].

Оскільки предмет нашого дослідження пов'язаний 3 проблемами етичного вибору в сфері інформаційних відносин, зокрема, в бібліотечній справі, варто звернути увагу на розроблений В. С. Пашковою посібник [9], присвячений інтелектуальній свободі, доступності інформації в демократичному суспільстві, морально-етичним засадам бібліотечної професії та проблемам конфіденційності в бібліотечно-інформаційному обслуговуванні.

Ці та інші проаналізовані публікації, будучи методологічно важливими для дослідження питань етики бібліотечної діяльності у забезпеченні вільного доступу до інформації в сучасних умовах, все ж не дають відповіді на питання: яким 3 принципів повинен 
керуватись бібліотекар: наданням свободи доступу до інформації чи міркуваннями щодо того, яким чином вона буде використана?

Виклад основного матеріалу. У професії бібліотекаря, більш ніж в будь-якій іншій, суспільство акцентує увагу не просто на рівні освіти, обсязі спеціальних знань, вмінь, навичок, але й на моральних якостях працівника. Об’єктом діяльності бібліотекаря є люди, але крім професійного спілкування 3 ними бібліотекар перебуває в постійному, специфічному контакті 3 джерелами інформації: збирає, зберігає і доносить їх зміст до широких верств населення. Сьогодні бібліотекарі всіх країн створюють науковообгрунтовану, узгоджену з практикою систему професійних вимог, які регламентують їх діяльність. В основі цих вимог лежать професійні етичні норми, які повинні дотримуватися кожним, хто переступив поріг бібліотеки [2, с. 60]. 3 проголошенням незалежності України в українських законах знайшли відображення норми вияву поваги до гідності людини. Вперше, у Законі України «Про бібліотеки і бібліотечну справу» виділено правову норму, яка забезпечує дотримання бібліотекарем певних етичних норм, закріплює конфіденційність інформації, а саме в ст. 5 записано: «Забороняється використовувати дані про користувачів бібліотеки та їхні читацькі інтереси з будь-якою метою, крім наукової» [10]. «Кодекс професійної етики бібліотекаря», поміж інших етичних положень, які рекомендуються для дотримання кожним бібліотекарем, встановлює принципи етики щодо відкритого доступу до інформації та інтелектуальної власності. Ці концепти 
$€$ основоположними для розвитку особистості та використання інформаційних ресурсів у інформаційному суспільстві [2].

Однак процеси, що відбуваються внаслідок соціальнополітичних чинників, а також актуалізація питань етики використання інформаційних ресурсів призводять до того, що питання вільного доступу до інформації сьогодні дискутуються і не $\epsilon$ однозначними. Суперечність полягає в «абсолютизації» інформаційної функції бібліотеки, оскільки позиція бібліотекаря, який розглядає вільний доступ до інформації як невід'ємне право особистості й протидіє обмеженню доступу до бібліотечних матеріалів, у змінюваному світі знаходиться не тільки в категорії «не суперечить законодавству», а в певних ситуаціях потребує в професійній діяльності бібліотекаря етичного вибору: надати інформацію чи ні?

Фундаментальною ознакою інформаційного суспільства $\epsilon$ свобода доступу кожного до інформації. Кодекси професійної етики бібліотекарів практично усіх країн постулатом своєї діяльності, поміж інших цінностей та моральних ідеалів, фіксують забезпечення безперешкодного доступу до інформації.

Українська бібліотечна асоціація [12] утверджує такі основні морально-етичні норми професійної бібліотечної діяльності щодо доступу до інформації:

-дотримуватись принципів інтелектуальної й інформаційної свободи;

-протистояти спробам цензурувати читання, формування фондів бібліотек, надання доступу до інформації; 
-поважати людську гідність і реалізовувати право особи на отримання інформації;

-забезпечувати високий рівень обслуговування, створювати умови для рівноправного, вільного та комфортного доступу користувачів до інформаційних ресурсів;

-використовувати всі можливості для надання користувачам бібліотек якнайширшого доступу до інформації та ідей в будьякому форматі;

-дотримуватись нейтральності й неупередженої позиції щодо збирання та організації доступу до інформації й надання послуг, прагнути до того, щоб особисті переконання не заважали вільному доступові користувача до інформації.

Очевидно, що забезпечення свободи доступу до інформації $є$ наріжним каменем у Кодексі професійної етики бібліотекаря.

Загалом, до проблеми вільного доступу до інформації може бути два основних методологічних підходи:

- абсолютна свобода доступу до будь-якої інформації;

- доступ до інформації, враховуючи зв'язок між одержаною інформацією та їі використанням.

Сьогодні жодна країна не може собі дозволити перший підхід, хоча 6 із міркувань обмежень, встановлених законом в інтересах національної безпеки, територіальної цілісності або громадської безпеки, для охорони порядку або запобігання злочинам, для охорони здоров’я або моралі.

Другий підхід створює етичну ситуацію у спілкуванні «бібліотекар - читач», надаючи бібліотекарю функції цензора, 
делегуючи йому право й можливість самостійно прийняти рішення, яке може суперечити не тільки Кодексу його професійної етики, а й законодавству, яке регулює відносини в інформаційній сфері.

Виникають ситуації, коли забезпечення вільного доступу до інформації не заборонене на законодавчому рівні, а $є$ етичною проблемою, що потребує від бібліотекаря власного вибору, таким чином викликаючи певну суперечність у реалізації бібліотекарем принципів Кодексу професійної етики.

На один 3 проявів такої суперечності вказано в роботі О. Козлової [5]. Увагу дослідниці зосередилась на діяльності шкільних бібліотек, на процесі переходу від ідеології активного впливу на читача до свободи вибору ним інформації. Вказуючи на те, що не доводиться чекати від дітей та підлітків саморегуляції у виборі джерел інформації, науковець звертає увагу на проблему обмеження в доступі до інформації в бібліотечному обслуговуванні, наголошуючи на усвідомленні бібліотекарем своєї педагогічної місії.

Звертається також увага на те, що на порядку денному не просто бібліотечна етика, а інформаційно-бібліотечна етика як сукупність етичних взаємовідностин у процесі бібліотечної діяльності з забезпечення доступності інформациї [4].

Ситуації, коли принципи вільного доступу до інформації суперечать певним етичним принципам, виникають у широкому спектрі діяльності освітньої та наукової спільноти.

Поміж відносин, які складаються в галузі поширення i використання інформації в науковому та освітньому процесі, 
знаходяться ті, що вкладаються в поняття «академічна недоброчесність» - плагіат, списування, використання курсових, дипломних робіт та дисертацій, виконаних на замовлення, які стосуються сфери інформаційної етики.

Початково інформаційна етика як самостійна дисципліна оформилась у США в сфері бібліотечно-інформаційних наук, надалі еволюціонувавши до проблем комп'ютерної етики, медіаетики тощо.

Термін «інформаційна етика» в науковому дискурсі розуміється сьогодні в фактично двох протилежних значеннях, які можна окреслити такими визначеннями:

-інформаційна етика визначається як галузь етики, яка фокусується на взаємозв'язку між створенням, організацією, поширенням та використанням інформації, а також етичними стандартами й моральними кодексами, які регулюють поведінку людей в суспільстві.

-інформаційна етика - дисципліна, яка досліджує моральні проблеми, що виникають у зв’язку з розвитком і використанням інформаційних технологій і пов'язана з комп’ютерною етикою.

He заперечуючи зв'язок інформаційної етики 3 інформаційними технологіями, які полегшують доступ до інформації, іiі організацію та поширення, у даній науковій роботі ми будемо розуміти інформаційну етику базуючись на концепті «інформація».

Предметом інформаційної етики $є$ взаємозв'язок між створенням, організацією, поширенням і використанням інформації 
та етичними стандартами і моральними нормами, які регулюють поведінку людини в суспільстві.

У діяльності вузівських колективів, які $\epsilon$ унікальним поєднанням спільної діяльності учених, докторантів, аспірантів та студентів, інформаційна етика безпосередньо стосується таких питань як етика ученого та академічна доброчесність.

Варто зазначити, що бібліотеки і бібліотекарі не залишаються осторонь процесу просвітницької діяльності: в межах проекту УБА «Культура академічної доброчесності. Роль бібліотек» розроблено «Профіль компетентностей бібліотекарів 3 академічної доброчесності» [11], розробляються методичні поради за участі бібліотек у навчанні студентів академічній доброчесності [8]. Це природно, беручи до уваги соціальне призначення бібліотеки, задеклароване в «Кодексі професійної етики бібліотекаря» України: «...ми усвідомлюємо гуманістичну місію нашої професії, сприяємо морально-етичним пошукам людини в пізнанні навколишнього світу».

Разом 3 тим, бібліотекарі не виключають можливість створення ситуацій всередині самої бібліотеки, які б потребували аналізу з етичної точки зору. Наприклад, у посібнику [9] наведено завдання, яке пропонує вирішити етичну дилему: чи повинна бібліотека пропонувати студенту (учню), який прийшов 3 певною темою реферату, не пошук потрібних джерел в Інтернеті, а вже готовий реферат із дібраної й створеної співробітниками бази даних рефератів? 
У зв'язку з актуалізацією етичних проблем у інформаційному просторі педагогічні працівники виділяють розгляд інформаційноетичних ситуацій в окрему навчальну дисципліну [4]. Пропонуючи для іiі вивчення педагогічну технологію кейс-стаді, автори навчального посібника в представлених інформаційно-етичних кейсах звертаються i до бібліотечно-інформаційного обслуговування студентів та науковців, пропонуючи можливі ситуації, які потребують аналізу та критичного оцінювання. У діяльності бібліотекаря, зокрема що стосується бібліотек ВНЗ, можуть виникнути ситуації, в яких постає суперечність між тим, як приписує діяти кодекс професійної етики бібліотекаря - надання вільного доступу до інформації - i сучасними імперативами академічної доброчесності та інформаційної етики в науковій та освітній діяльності.

Поміж багатьох інформаційно-етичних ситуацій в бібліотечному обслуговуванні, представлених у посібнику [1], які пропонуються для аналізу та оцінювання, $є$ такі:

-чи повинен бібліотекар надати літературу читачу, який шукає ії за темою «Як обійти податкове законодавство?»;

-чи повинен бібліотекар задовольнити запити аспірантів та молодих науковців, які в значній кількості приходять до бібліотеки університету з проханням надати їм літературу іноземною мовою та iii варіант рідною мовою, оскільки для бібліотекаря очевидно, що ці молоді люди готуються до здачі кандидатського мінімуму 3 іноземної мови і не хочуть обтяжувати себе їі вивченням? 
Не аналізуючи за суттю запропоновані ситуації, а також ті, які виникають у щоденній діяльності бібліотечного працівника, запитаймо: чи повинен бібліотекар у непередбачених законодавством ситуаціях брати на себе функції цензора? Відчуваючи свою відповідальність як інформаційного посередника, чи повинен бібліотекар присвоювати собі право на власний розсуд, керуючись власним життєвим і професійним досвідом, базуючись на власному рівні культури і розумінні ситуації, відмовити в доступі до інформації читачеві, якщо йому здається, що читач може iii використати якось інакше, ніж уявляє собі бібліотекар?

Безперечно, практично неможливо прогнозувати й формалізувати всі ситуації, які можуть виникнути в повсякденній роботі бібліотекаря. Однак очевидно, що сьогодні бібліотекар знаходиться в ситуації формування нової етики - етики свободи i відповідальності. Формування такої етичної парадигми не є чимось новим для бібліотеки, оскільки і свобода, і відповідальність завжди були притаманні бібліотечній професії й гуманістичній та культурно-освітній місії бібліотеки.

Висновки. Свобода доступу до інформації, сформульована як вища морально-етична цінність у професійній діяльності бібліотекаря сьогодні потребує уточнення й дискусії в науковому співтоваристві та в середовищі професійної бібліотечної спільноти.

Беручи до уваги динамічні соціокультурні зміни в інформаційному просторі імперативом $є$ наукові дослідження проблем інформаційної етики й освітня підтримка (в будь-яких формах навчальної діяльності) діяльності бібліотекарів-практиків. 


\section{Список використаних джерел}

1. Алтухова Г. А. Профессиональная этика библиотекаря : учеб. пособие для вузов и сред. проф. учеб. заведений культуры и искусства / Г. А. Алтухова. - [2-е изд., испр. и доп.]. - Москва : Изд-во Моск. ун-та культуры и искусств : Профиздат, 2000. - 103 с.

2. Алтухова Г. А. Этические нормы библиотечного труда / Г. А. Алтухова // Мир библиотек сегодня. - Москва, 1998. - № 1. C. $60-65$.

3. Информационно-этические ситуации в научной деятельности вуза [Электронный ресурс] : учеб.-метод. пособие / T. В. Еременко, О. Г. Меркулова ； Ряз. гос. ун-т имени С. А. Есенина. - Электрон. текстовые дан. (1 файл.: 863 КВ).Рязань, 2016. - 1 электрон. опт. диск (CD-ROM).- Систем. Требования: IBM / PC; Windows XP и выше ; 256 MB RAM ; свободное место на HDD 25 MB ; Acrobat Reader 3.0 или старше.Загл. с экрана.

4. Кириченко М. О. Iнформаційна антропологія й інформаційна етика як складники формування ідеології інформаційного суспільства / М. О. Кириченко // Актуальні проблеми філософії та соціології. - 2017. - Вип. 16. C. $51-53$.

5. Козлова О. В. Между ответственностью и свободой выбора / О. В. Козлова // Библиотечное дело. - 2010. - № 7(121). [Электронный ресурс].- Режим доступа : http://www.bibliograf.ru/issues/2010/4/148/0/1314/. - Загл. с экрана. 
6. Махотина Н. В. Международная политика в области ограничения доступа к информации в зарубежных библиотеках / Н. В. Махотина // Библиотеки нац. акад. наук: проблемы функционирования, тенденции развития. - 2016. - Вып. 13. - С. 9196.

7. Миролюбенко Г. А. Інформаційна етика в просторі сучасних комунікативних процесів (філософсько-етичний аналіз) : дис. ... канд. філософ. наук : 09.00.07 / Г. А. Миролюбенко ; Київ. нац. ун-т імені Тараса Шевченка. - Київ, 2011. - 223 арк.

8. Навчання студентів академічній доброчесності у бібліотеці ВН3: методичні поради / автори-укладачі: Л. В. Савенкова, С. О. Чуканова ; редколегія: В. С. Пашкова, О. В. ВоскобойніковаГузєва, Я. С. Сошинська ; Українська бібліотечна асоціація. - Київ : УБА, 2016. - Електрон. вид. - 1 електрон. опт. диск (CD-ROM). $39 \mathrm{c}$.

9. Пашкова В. С. Інтелектуальна свобода та доступність інформації в демократичному суспільстві. Етика бібліотечного працівника : посіб. для тренерів за прогр. підвищ. кваліфікації / Укр. бібл. асоц., Нац. акад. керівних кадрів культури і мистецтв, Центр безперервн. інформ.-бібл. освіти, Головний тренінгов. центр для бібліотекарів; В. С. Пашкова. - Київ : Самміт-книга, 2012 $68 \mathrm{c}$.

10. Про бібліотеки і бібліотечну справу: Закон України від 16.03.2000 p. № 1561-III // Законодавство - бібліотекам України : довідкове видання. - Київ, 2001. - Вип. 1. - С. 3-16. 
11. Профіль компетентностей бібліотекарів 3 академічної доброчесності [Електронний ресурс]. - Режим доступу: https://ula.org.ua/news/3787-profil-kompetentnostei-bibliotekariv-zakademichnoi-dobrochesnosti. - Назва з екрану.

12. Українська бібліотечна асоціація [Електронний ресурс].Режим доступу: https://ula.org.ua/. - Назва з екрану.

13. Чхеайло I. I. Інформаційна етика як моральна регуляція сучасного суспільства / I. І. Чхеайло, А. А. Чхеайло // Вісн. нац. унту Юрид. акад. України імені Ярослава Мудрого. Серія: Філософія, філософія права, політологія, соціологія. - 2015. - № 3. - С. 30-40.

\section{References}

1. Altuhova, G. (2000). Professional Ethics of Librarianship. Moscow: Proizdat.

2. Altuhova, G. (1998). Ethical standards of library work. Mir bibliotek segodnja [The world of libraries today], no. 1, pp. 60-65.

3. Eremenko, T., Merkulova, O. (2016). Information and ethical situations in scientific activity. Rjazan': Rjazanskij gosudarstvennyj universitet imeni S. A. Esenina.

4. Kyrychenko, M. (2017). Information anthropology and information ethics as components of the formation of the ideology of information society. Aktualni problemy filosofii ta sotsiolohii [Topical problems of philosophy and sociology], no. 17, pp. 51-53.

5. Kozlova, O. (2010). Between responsibility and freedom of choice. Bibliotechnoe delo [Librarianship], no.7(121). Available at: 
<http://www.bibliograf.ru/issues/2010/4/148/0/1314/> [Accessed 20 November 2017].

6. Makhotina, N. (2016). International policy on limiting access to information in foreign libraries. Biblioteki natsyonal'nyh akademij nauk: problemy funktsyonirovanija, tendentsii razvitija [Libraries of national academies of sciences: problems of functioning, development tendencies], no. 13, pp. 91-96.

7. Myroliubenko, H. (2011). Information ethics in the space of modern communicative processes (philosophical and ethical analysis). D.Ed. Taras Shevchenko National University of Kyiv.

8. On Libraries and Library Affairs: Law of Ukraine dated March 16, 2000 No.1561-III. Zakonodavstvo - bibliotekam Ukrainy [Legislation to libraries of Ukraine], issue 1, pp. 3-16.

9. Pashkova, V. (2012). Intellectual freedom and information accessibility in a democratic society. Library Worker Ethics: Guide for advanced training coaches. Kyiv: Summit Book.

10. Savenkova, L., Chukanova, S. eds. (2016). Teaching academic integrity in a library of a higher educational institution. Kyiv: Ukrainska Bibliotechna Asotsiatsiia.

11. A profile of the librarians' competences on academic integrity. Available at: <https://ula.org.ua/news/3787-profil-kompetentnosteibibliotekariv-z-akademichnoi-dobrochesnosti> [Accessed on 10 September, 2017].

12. Ukrainian Library Association. Available at: https://ula.org.ua/. [Accessed on 25 September, 2017]. 
13. Chkheailo, I. (2015). Information ethics as a moral regulation of modern society. Visnyk Natsionalnoho universytetu «Yurydychna akademiia Ukrainy imeni Yaroslava Mudroho». Seriia. Filosofiia, filosofiia prava, politolohiia, sotsiolohiia [Bulletin of Yaroslav Mudryi National Law University. Series. Philosophy, philosophy of law, political science, sociology], no. 3, pp. 30-40.

(C) Конюкова I. Я., 2017 